This item was submitted to Loughborough's Research Repository by the author.

Items in Figshare are protected by copyright, with all rights reserved, unless otherwise indicated.

\title{
Improving public urban services through increased accountability
}

PLEASE CITE THE PUBLISHED VERSION

PUBLISHER

(C) ASCE

LICENCE

CC BY-NC-ND 4.0

\section{REPOSITORY RECORD}

Cavill, Sue, and M. Sohail. 2019. "Improving Public Urban Services Through Increased Accountability". figshare. https://hdl.handle.net/2134/3850. 
This item was submitted to Loughborough's Institutional Repository (https://dspace.lboro.ac.uk/) by the author and is made available under the following Creative Commons Licence conditions.

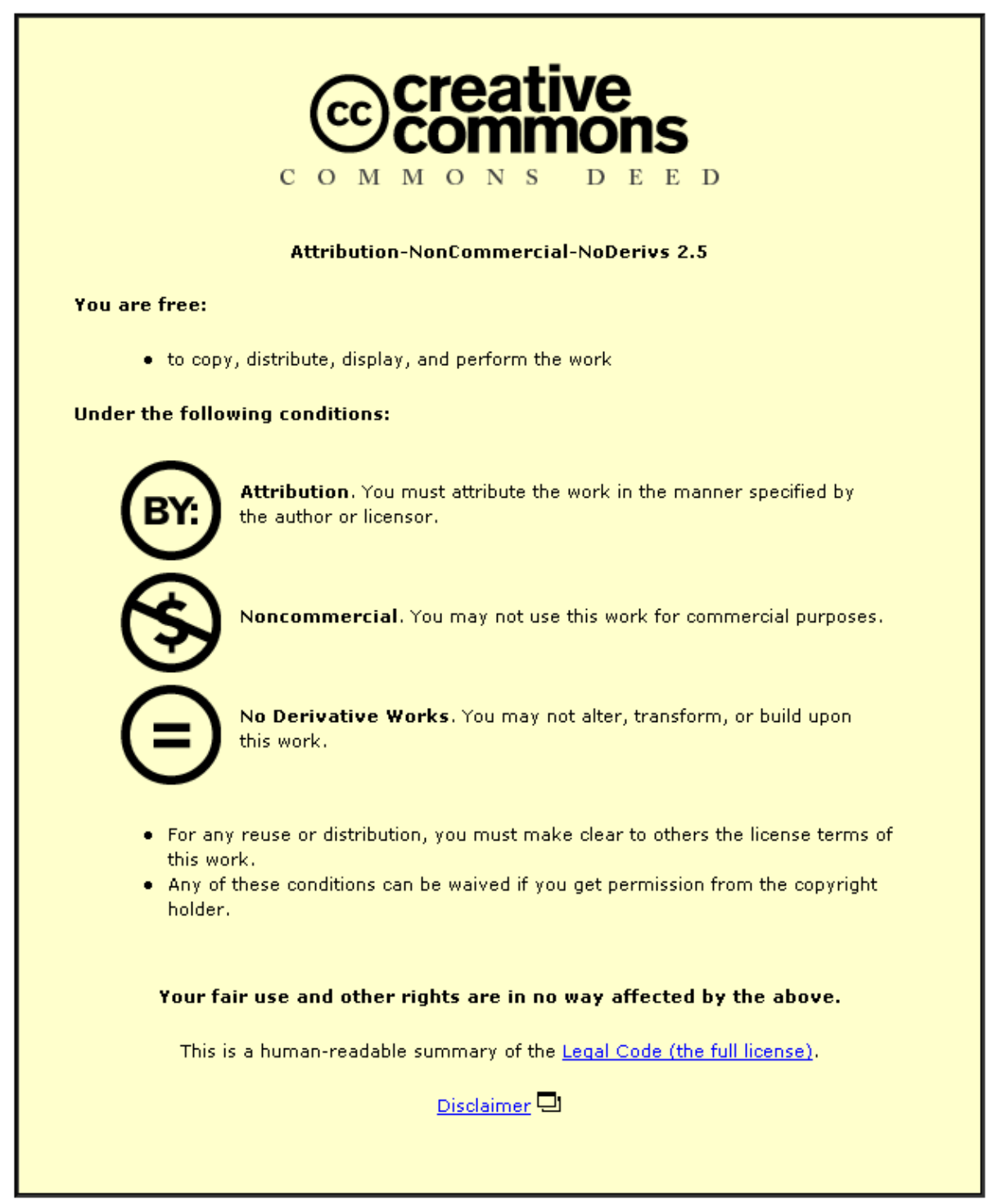

For the full text of this licence, please go to: http://creativecommons.org/licenses/by-nc-nd/2.5/ 


\title{
Improving public urban services through increased accountability
}

\author{
S Cavill and M Sohail
}

\section{ABSTRACT}

This article is concerned with the potential of accountability to improve the performance of public urban services. A number of assumptions are made in the literature relating to accountability; these concern the necessity of multiple strategies of accountability, information symmetries, sanctions, trust, homogeneous service users, community-level answerability, incentives, self-regarding behaviour, and for users' voice to be heard in service delivery. It is the purpose of this paper to reconsider these theoretical propositions for the functioning of accountability in light of practical experience from UK, South Africa, Bangladesh and South Korea. Each of these case studies was selected to illustrate a different form of accountability. The forms of accountability investigated in this research are professional, political, user and managerial accountabilities. An assessment is made of whether accountability is demonstrated in these case studies in the way predicted by the literature. The empirical data demonstrates that factors like multiple strategies and information/resource symmetries are critical to accountability but that there is only partial evidence to support the need for sanctions, trust, incentives, self-interest, and user voice for effective service delivery. The research indicates the need for greater emphasis on the operation and maintenance of urban services and direct accountability to service users. However the assumption that service users are homogenous is disputed. This article concludes with a review of the practical implications of strengthening accountability as a means to improve the performance of urban services. 


\section{INTRODUCTION}

“The success of service delivery depends on whether institutions of service provision are accountable to citizens” (Ahmed et al, 2004)

This paper is concerned with accountability for urban services. The term ‘urban services' refers to such services as water supplies, sanitation, drainage, access roads and paving, street lighting, solid waste management and community buildings.

Stakeholders in developing countries and developed countries alike have concerns over aging and obsolete urban infrastructure, which is in need of repair, replacement and upgrading. Historically, the provision of urban services was seen as the responsibility of the state, yet internationally governments have been unable to provide, operate and maintain public services in line with rapid urbanization, resource deficiencies, poor urban management and population growth. Furthermore, supply driven approaches to service delivery are said to have created urban services that are inefficient, ineffective and unresponsive to local specificities (Rubin, et al 2004; Henry, 2002). The consequences of these failures are of particular importance to poorer and discriminated against people, who typically lack both equitable access to public services as well as effective mechanisms to ensure that their voice is heard in service delivery (Narayan et al., 2000; 270). Instead it is argued that a more performanceoriented approach to service provision is required (Osbourne and Gaebler, 1993; Luce \& Henry, 2002; Miller, 2002; Hunsaker, 2001; Padmanabhan and Katti, 2002; Zitomer, Gabor \& Johnson, 2003).

A renewed emphasis on the outputs of urban services has put the issue of accountability on the agenda. Enthusiasts in donor agencies and academia alike see improved outputs, greater responsiveness to the needs of service users and sustainability as a likely consequence of greater urban service accountability (World Bank, 2004; Cywinski, 2001; Siller, 2001; Steinmann, 2003; Rassafi \& Bagheri, 2002). Accordingly, attention has been given to apply ethics to engineering (Grant, 2001; Cochran, 2002; Lang, 2003) together with ways of increasing opportunities for service users to express their demands through voice and consumer style behaviour as well as making the public sector more accountable in the provision of urban services. 


\section{WHAT IS ACCOUNTABILITY?}

By way of general definition: “A is accountable to B when A is obliged to inform B about A's (past or future) actions and decisions, to justify them and to suffer punishment in the case of eventual misconduct” (Schedler in Schedler, Diamond, Plattiner, 1999). Jabbra and Dwivedi (1989) argue that the term ought to include administrative, legal, professional, political and moral components. O’Donnel (1999) states that accountability operates in different directions, and has distinguished between horizontal accountability (the capacity of state institutions to check abuses by other public agencies and branches of government) and vertical accountability (the means through which citizens, mass media and civil associations seek to enforce standards of good performance on officials). Recently, citizens have been involved directly in the workings of horizontal accountability institutions, for example, through public hearings or participatory auditing. Goetz and Gaventa (2001) call this “diagonal accountability”.

\section{HOW DOES ACCOUNTABILITY WORK?}

The "principal agent" theory is typically used to analyse the problem of accountability. This framework describes a relationship in which a principal (service users in this case) attempts to secure services from an agent (service providers). Agents are expected to hide the information that principals require to monitor their performance and, thus, contracts, incentives and sanctions are needed to induce agents to deliver the desired type and level of performance. Accountability arrangements can foster better services by reducing the transaction costs of service users incurred in monitoring service delivery. It is suggested that greater accountability will then promote improved capacity and ability of local government to meet the challenges of urban service provision.

\section{ACCOUNTABILITY FOR URBAN SERVICES}

Accountability has emerged as an international issue, and talk of accountability has become commonplace in service delivery debate (Paul, 2002; Goetz and Gaventa, 2001; Deichmann \& Lall, 2003; Rakodi, 2003; Grindle, 2003; Casely, 2003; World Development Report, 2004). Where once the focus of accountability was on government, attention is increasingly paid to the relationship between 
front line service providers and users. Proponents of more accountability claim that frontline service providers have too much discretion, and too few sanctions, in the context of bureaucratic, centralized service provision. This has allowed service providers to become untrustworthy, unaccountable and unproductive. Accountability can be improved by service users participation in service delivery, for example in setting performance plans, goals and standards for service delivery as well as evaluating services in terms of outcomes. User voice can have a disciplining effect, ensuring that service delivery becomes more efficient and effective (Devas \& Grant, 2003).

The main reasons advanced for applying accountability to the delivery of urban services can be summarised as:

- Incentives: To reduce the discretion of front line service providers in decision-making at the point of delivery.

- Information symmetries: Greater accountability can make information on the performance of services more widely available.

- Users' voice: Attempts are being made to rework the relationships involved in service delivery so that service providers are more directly accountable to service users.

- Sanctions: Accountability arrangements can change levels of tolerance for poor service, leading citizens to reveal their demand for better quality and more accountable urban services at the community level.

- $\quad$ O\&M is neglected in practice: Greater accountability to service users is thought to lead to better monitoring of quality and standards of service, and more effective use of resources.

- Community-level answerability: As well as extending access to urban services greater accountability of service providers and policy makers can be used to protect the quality of supply available to marginal and excluded groups in society.

- $\quad$ Trust: Antipathy towards provision of urban services by a large, hierarchical, public sector has led to attempts to reduce and reorganise the public sector and improve the accountability of its activities.

- Multiple strategies of accountability: In some countries the private sector, NGOs and communitybased organisations are service providers. Attention is being paid to the allocation of accountability in the context of fragmented service delivery. 
- Homogeneous service users: There is an implicit assumption that the rich and poor are able to secure accountability for urban services through similar sets of relationships.

- Self-interest/self-regarding behaviour: Service users and providers are essentially deemed selfinterested and utility maximising

\section{METHODOLOGY}

A literature review revealed a number of propositions for the effective functioning of accountability; these included the need for multiple strategies of accountability, information symmetries, sanctions, trust, homogeneous service users, community-focused answerability, incentives, self-interest/selfregarding behaviour, and users' voice. Using the case study methodology, this research set out to test these propositions. Case studies were chosen from the UK, South Africa, Bangladesh and South Korea on the basis a known improvement to accountability for urban services. The research findings are based on information collected from semi-structured interviews with front line service providers, closed answer questionnaires with service users, document review, and direct observation in both deprived and non-deprived areas of the study locations. A random survey of about 100 respondents was conducted in deprived (squatter settlements) and non-deprived areas of Mdantsane, Dhaka and Seoul, and was intended to give an overall impression of user satisfaction rather than a statistically significant sample. The data was collected between July 2002 and July 2003. A short case study is given below and summarised in table 1, before the key findings from an initial data analysis are presented.

\section{THE CASE STUDIES}

The Bristol case study illustrates professional accountability through attempts to improve the design and delivery of services as well as the self-regulation of service providers through professional, ethical and technical standards. Service delivery has been redesigned to create integrated and more locally responsive delivery of waste collection, street cleaning, grounds maintenance, household bulky waste collection, gully emptying and recycling services in a neighbourhood of Bristol called Barton Hill. Project Pathfinder is a partnership between Bristol City Council, SITA GB Ltd, ResourceSaver (an NGO which operates the kerbside "black box" recycling collection service under sub-contract) and 
Community at Heart (a resident-led organization established to deliver the New Deal for Communities anti-deprivation programme in the area). The principles of Pathfinder include the location of a multiskilled team in a dedicated area, with a local one-stop shop to act as a coordinating base; better customer relations; and more efficient and effective service provision.

The South African study focuses on political accountability in attempts to get more appropriate and accessible urban services. This study makes reference to popular participation in government service delivery through direct and representative methods. Local government in South Africa is supposed to be developmental (i.e. it works with citizens to find sustainable ways of meeting their needs and improving the quality of their lives) and the Municipal Structures Act (1998) outlines the role of ward committees as a key mechanism for involving communities in matters of service delivery. Ward committees assist and advise their ward councillor, act as a communication channel between the community and ward councillor, ensure that their ward councillor accounts for his/her actions, and encourage resident participation in attempts to improve the quality of life in their ward. Observations are based on a study of a suburb of Buffalo City called Mdantsane, which, under apartheid, was developed as a township.

The Bangladeshi case study is intended to illustrate attempts to increase user accountability in Dhaka; this approach is based on ideas of empowerment, and is intended to overcome producer dominance. Two specific forms of user accountability in Dhaka were investigated that reflect the growing voice of civil society for more accountable and better quality services: a Scorecard to assess public service delivery in terms of performance and the degree of satisfaction with services as well as the coproduction between Dhaka City Corporation, NGOs and community initiatives to fill the gaps in urban service provision, for example in waste collection and water and sanitation projects.

The South Korean case study illustrates managerial accountability through improvements to the responsiveness of service providers in Seoul. Complaints are recognized as an important way to monitor service performance in this model. Following the IMF crisis in 1997, Mayor Goh implemented a reform of Seoul Metropolitan Government on the basis of zero tolerance of corruption. Mayor Goh abolished public officials discretionary power, transparency was increased through "benign ethical competition” between departments (as promoted by the Citizen Evaluative Survey); as well as 
online information disclosure systems; meetings with citizens (Saturday Date with the Mayor); and Corruption Report Card to the Mayor.

\section{TESTING THE PROPOSITIONS FOR ACCOUNTABILITY}

The literature presents a range of factors that influence accountability for service provision, which are often taken as given in theory and practice. However, these propositions frame the way in which urban services are presented, and their problems are understood. They also have implications for the particular nature and role that accountability has been set up to play. It is important therefore that these assumptions are identified and tested. The intention here is to problematize the meaning of accountability by reconsidering these propositions in light of the practical experience and empirical data documented in the fieldwork. In particular, these assumptions are tested to see if accountability is demonstrated in the case studies in the way predicted by the literature review, and the usefulness of these propositions is reviewed. These findings are summarised in Table 2.

\section{- Multiple strategies}

The literature suggests that accountability works best when multiple strategies are encouraged. The case studies seem to support the proposition.

Finding: Respondents from deprived areas use multiple strategies to cope with failing services.

The research showed that when respondents in deprived areas encountered a problem with urban services they were more likely to contact or vote for a politician, hold a public meeting, join a user group, protest or demonstrate, or organise a petition. Furthermore, deprived respondents tended to seek collective, rather than individual forms of accountability. The poor tended to have a repertoire of accountability related activities and strategies to deal with failing urban services, presumably just as they adapt, change and diversify their survival strategies. In contrast, wealthier respondents from nondeprived areas tended to have one predominant strategy, which is a dependence on the mechanisms offered by service providers (free phones, Internet sites, visits to offices, suggestion boxes and so on). Respondents in non-deprived areas seemed more satisfied with urban services than those who preferred ad-hoc accountability arrangements. Whilst service provider-related mechanisms for accountability 
seem to work better than ad hoc arrangements in terms of improving services, it is unclear whether these channels would be as effective for poorer respondents.

Finding: Accountability isn't something that is achieved once and for all. Accountability was lost and regained many times in the case study experiences. For example, accountability for urban services in Bristol has been lost at times because of SITA's resources constraints and operational needs. This loss of accountability made residents suspicious that they were being manipulated or co-opted according to agendas that are hidden to them, and feeling that accountability may be used as a PR tool whilst business goes on as usual. The key to effective delivery of urban services is that service users know how to re-establish accountability.

Finding: There is a need to review how accountability is defined. Service providers and users in the case studies had somewhat conflicting ideas of accountability. Service providers considered themselves accountable for technically competent service delivery. Service provider's definitions of accountability tended to reflect answerability for their decisions or action. But accountability was differently constructed from users point of view. Most service users thought providers ought to be accountable for ensuring participation in decision making and responding to users complaints.

Finding: Accountability only exists insofar as people use it. In Dhaka it was stated that slum dwellers now 'play' with service providers in their attempts to get better services. In this metaphor accountability doesn't have an inherent existence unless people engage with it, perform it, or take part in it. Playing requires service users and providers to be more creative and adaptive, instead of sticking to procedures in a rigid or systematic way. Playing also requires service providers expand preconceived notion of limits to their responsibility.

\section{- Information and other resource symmetries}

Information on the performance of services can overcome weak horizontal accountability between policymakers and providers, create competition in service delivery (in terms of political and 
commercial reputations of service provides) and solve collective action problems for service users. The case studies seem to support the proposition.

Finding: Information asymmetries had been reduced in service delivery. Information asymmetries had been addressed in the case studies in a variety of ways. For example, in Seoul the Internet was used to maximise the accessibility of service providers to citizens by cutting through administrative complexity and red tape. In Bristol residents were given a copy of the street cleansing schedule and cleanliness standards to enable them to monitor standards of service delivery. In all cases a sympathetic media had a key role as both a watchdog on service providers, awareness raising tool, and a communication channel for the public. This research also raised the issue of information asymmetries between front line service providers and management

Finding: Information asymmetries can be reduced through dialogue. The accountability 'problem' has been articulated as one of communication. Improved communication, and especially 'voice', is needed to better understand customers' needs and priorities, as well as make services more efficient and effective. The distinction can be made between the kinds accountability for urban services that provide a top down, one-way transmission of information from service providers to service users, such as an explanation or justification for decisions, and those that propose a dialogue between service providers and users.

Finding: Accountability needs to be sustained. The sustainability of accountability itself was raised as a concern in the fieldwork. Certain service users preferred to engage with accountability in an ad hoc or disorganised way, with daily interactions with service providers more important in securing accountability than formal organisations. Initial enthusiasm in accountability reforms was found to wane as problems with services are solved, or when resource constraints prevented on-going action. Accountability was also seen to dissipate once political terms of office were up, or whenever contentious, long term and unpopular issues arose. In addition, where community participation had led to greater demands for local control over resources and more active involvement in decision-making, service provider enthusiasm for accountability has cooled. 
Finding: Accountability has a number of costs. The case studies demonstrated the costs of being accountable, for example in complying with accountability requirements, opportunity costs or alternatively the costs involved in attempting to avoid accountability or circumvent inspection.

\section{- $\quad$ O\&M is neglected in practice}

Operation and repair is critical to the success of urban services, however, in practice urban services often fail in terms of quality and quantity. Failing services has created a logic and legitimacy for greater accountability. The case studies demonstrate partial support for this claim.

Finding: The case studies showed that the most important outputs of service delivery are not always measurable. The literature advocates the use of performance indicators and reporting systems to judge the effectiveness of service delivery. The case studies showed that the outputs of service delivery are not always measurable. For example, in Bristol the main benefits of the service were in the way front line service providers improved the quality of life for residents in their role as informal community wardens, rather than the tonnage of waste collected. In Seoul, the principal benefit of accountability was to make it physically, socially and psychologically easier for citizens to approach the city hall, and in Mdantsane and Dhaka accountability led to empowerment and mobilisation at the grassroots level.

Finding: O\&M of urban services is often not a priority for municipalities. In certain cases public service providers did lack planned maintenance schedules and showed no evidence pointing to strategic approaches. O\&M of urban services is often not a priority for municipalities, despite the on-going and widespread nature of problems with O\&M. In Dhaka and Mdantsane service delivery was constrained by a lack of detailed records indicating asset location and condition at the ward level. Yet, in other cases, central and local government have taken the lead in improving O\&M.

Finding: Effective O\&M was improved by partnerships. The accountability arrangements demonstrated in the case studies typically involved building partnerships or alliances between business, public institutions and voluntary sectors. These kinds of partnerships required shared values, the resources to sustain partnerships, communication channels, as well as a sense of solidarity and 
motivation among multiple stakeholders. Partnerships were particularly important in deprived areas because many respondents reported multiple needs that are only capable of being solved by cooperation (such as poor environment, chronic health problems, stress, crime, low incomes, unemployment, poor housing, discrimination) that are complex and for which no single agency have specific responsibilities. In cases where community groups and a utility have co-produced O\&M, this has reaped substantial benefits for low-income communities, as in Dhaka.

Finding: Innovation in service delivery promoted O\&M. Many of the examples of accountability described in the case studies involved experimentation with service delivery, like water and sanitation projects in the slums of Dhaka. Many of these instances involved NGOs, who were relatively less accountable than government, and so have the flexibility to innovate and pilot new approaches to service delivery in deprived communities. Enthusiastic, charismatic and influential people often initiated the accountability arrangements, these people often had an ambitious personal commitment to greater accountability, and the ability to mobilise resources.

Finding: Accountability is also necessary within service provider agencies. There is a tendency to see accountability exclusively in terms of external relations between service providers and service users. The accountability of management to front line service providers within service delivery agencies has been overlooked. Management are accountable to staff, to whom they have obligations as employers in employment legislation and regulations to prevent discrimination. They have responsibility to promote equality in fair employment practices, implement whistle blowing procedures, as well as for training to develop knowledge and expertise.

\section{- Sanctions are needed for accountability}

Service providers are often at an advantage in service provision in terms of knowledge and power. Service providers can be made more accountable through improved supervision, together with professional sanctions and fostering citizen's voice and choice in service delivery. The case studies seem to partially support the proposition. 
Finding: In practice service users have few sanctions to use as leverage to demand better services. The theory suggests that, to be fully accountable, implies the use of sanctions. Although attempts were made to draw service users in as monitors of service delivery, users typically lacked effective sanctions to enforce a favourable response. Scott (1985) talks about 'weapons of the weak' through which subordinate groups can critique the powerful in society, for example, backbiting and grumbling and these strategies were very much in evidence in the deprived areas of the case studies.

Finding: The role of payment for services as a sanction in service delivery. The theory suggests that payment for services can amplify voice and make service providers responsive to needs if payment is withheld. However, the case studies revealed that, withholding payment was an ineffective way of seeking to improve services, often resulting in disconnections rather than better services. Furthermore, some respondents were willing to trade reduced service levels, and potentially reduce accountability, for lower council tax.

Finding: Embedding service providers in communities can be a disincentive to front line service providers. SITA planned to recruit staff for the Pathfinder team from staff who lived locally. However, this strategy failed precisely because of the kind of local accountability it would involve. Some people didn't apply for the project because they didn't want to be 'bothered in the pub on a Friday night’ by disgruntled residents.

Finding: Forms of accountability can be traded off against each other. In the Dhaka frontline workers are presented with a moral obligation (and financial incentive through bribes) to provide services to citizens regardless of the legal status of their dwellings. Moral accountability in this case led to water and sanitation projects in slum areas, made possible by loopholes in bureaucratic procedures - lack of administrative accountability. However, slum dwellers lack legal accountability and are unable to prevent evictions, despite paying for services. It was also clear in Mdantsane that accountability outcomes may be partially exclusive of each other. For example, water meters (and charging for water) might make services more financially accountable, but does not accord with users sense of social justice, i.e. moral accountability. 


\section{Finding: International pressures can be effective in making urban service delivery accountable to}

citizens. The World Bank and IMF have played key a role in promoting accountability initiatives at various times in UK, South Korea, Bangladesh, and South Africa, and aid conditionality has been as a sanction to discipline providers and substitute for weak voice of users. Ferguson's (1994) work is instructive in this case. He talks about the tendency of development agencies to perform sensitive political operations under the cover of neutral, technical operations.

\section{- Service providers are untrustworthy}

The institutions traditionally responsible for service delivery have been accused of abusing the trust of citizens, for example, in the use of public money as well as their capacity for impartial and predictable provision of urban services. Distrust has created a context conducive to demands for greater accountability. The case studies partly support the proposition.

Finding: Trust does matter in service delivery. Respondents in this research stated that, on the whole, they didn't trust services providers, but have no choice but to use certain services everyday, e.g. water supply. It might be concluded that trust is not important where there is no choice in service delivery. However, in Seoul respondents' distrust of the quality of tap water means scarce resources are diverted from core activities into information creation and dissemination.

Finding: Levels trust varies with the service provider. Respondents seemed to have a higher level of trust in local government that in the private sector. For example, in Bristol, although residents 'complain endlessly' about the council there is still an implicit confidence in them. Private sector involvement, on the other hand, can lead to mistrust, uncertainty and suspicion in service delivery and increase demands for regulation. The research demonstrates that trust in the private sector depends on service providers offering a level of care and interest in service users beyond the cash contract, for example by attending community events.

\section{- Homogeneous service users}


The literature tends to view service users either as a homogenous group, or else focuses on specific groups, such as poor people without recognising the range of service users and the interaction between these social groups. The case studies do not support the proposition

Finding: Some groups are better placed for acting on accountability arrangements. Certain service providers had little sympathy for people in deprived areas because, although they tend to have chronic and repetitive complaints about urban services, it was suggested that the residents tend to cause the problems themselves by blocking drains with solid waste, putting stones down the toilets, or dropping food wrappers in the streets. Service providers' responses made a moral distinction between the 'virtuous' service users, who should be helped, and the 'undeserving' users who get what they deserve because of their attitudes and behaviour. Nonetheless, other service providers were sympathetic and conscientious about expanding the service to slums, and improving service delivery in low-income areas.

Finding: Focusing on individual accountability of front line service providers is a symptomatic approach to a structural problem. The theory suggests that accountability in the provision of urban services requires a change in the attitudes, values and expectation of the individual. This assumption has parallels with those theories of development that require socio-economic change to be complemented by a change in the individual. However, the research shows that it is an important to adopt a systematic approach to accountability, which addresses the position of deprived people in society as well as the individual's values.

\section{- $\quad$ Service providers should be answerable to the community}

The literature suggests that accountability should be ‘dis-intermediated’ i.e. service providers should be directly accountable to service users; potentially this can remove rent seeking 'middlemen', such as policymakers. The case studies partly support the proposition.

Finding: Political accountability continues to have an important role in the delivery of urban services. The separation of responsibility for policy, service provision, and monitoring is thought to improve accountability in the provision of urban services. Despite attempts to flatten accountability, 
respondents in the case studies revealed that local politicians remain key channels for complaints about urban services, both at central government and ward level. Political accountability is important in the sense of re-intermediating the more vulnerable service users. However, this finding might also indicate the existence of patron-client relations in service delivery. Residents may have in effect traded their civic rights for material benefits and tenure security (Varley 1999).

\section{Finding: The extent to which accountability arrangements have made society more governable is}

debateable. In cases where accountability arrangements have coordinated users voice, such as ward committees in South Africa, this appears to have generated a consensus on a range of conflicting interests, reduced the number of competing claims on financially limited resources, and increased the efficiency both in responding to complaints and in the use of resources. However, in other cases where accountability arrangements have fragmented users voice, this can mean more problems are presented than can be dealt with by local government, which may lead to failure of services and governance.

Finding: Thought should be given to how to scale up accountability from the project context. Where projects have created 'islands' of accountability within cities (such as Project Pathfinder in Bristol, ward committees in Mdantsane and NGO service delivery in Dhaka), it is thought to promote competitive pressures in service delivery. However 'islands' of accountability raise concerns about 'a postcode lottery' of geographically varying outputs in service delivery, in addition to broader concerns about how to replicate and scale up accountability to larger areas.

Finding: Accountability reflects the broader socio-political context. South Korea, Bangladesh and South Africa have relatively recent experience of civil society demanding democratic reforms of the ruling authoritarian regime. These case studies highlight the role of civil society in promoting vertical accountability, particularly through alliances of civic associations. The case studies revealed that the respondents in deprived areas typically relied on previously successfully tactics (such as collective pressure, demos, public protests) to highlight problems with service delivery.

Finding: Accountability is improved through local action. Accountability for community level services can be described as a public good, and so suffers from collective action failures. Whether 
users take responsibility for shared services depends on their stake in the service, the incentive for action, and the kind of problem presented (i.e. breakdown or chronic issues that can be endured for long time). Introducing accountability reforms in conjunction with community development work seemed to prove complementary, where efforts to organise, support and involve residents in urban service delivery served to increase incentives for action and to foster stability in areas of high resident turnover.

\section{- Service providers and users need incentives for action}

Reforms in the delivery of urban services have focused on the incentives (often financial) needed to ensure that service providers focus on the outputs of services and results in service delivery, and have an interest in finding and fixing problems. Service users also need incentives to monitor urban services and overcome collective action failures. The case studies partly support the proposition.

Finding: Users don't necessarily require individual incentives to take action in service delivery. In interviews officials bemoaned the lack of community ownership of infrastructure in Mdantsane, citing the theft of cables, handrails, or manholes covers. However, residents demonstrated community ownership, such that slum dwellers often rely on residents in formal housing for their water supply and local strategies to reinstall disconnected services, undo flow restrictors, and reduce the cost of service through meter tampering.

Finding: Recognition should be give to the range of motivations affecting service providers. The research found that incentives relevant to more uniform and equitable provision of service are not necessarily associated with material benefits, but can be ideological, political or moral values, such as solidarity, mutual responsibility, and common good. The Project team in Bristol demonstrated an unusual commitment from low wage employees. Under Project Pathfinder, front line service providers gained work satisfaction and personal status, they felt empowered by jobs, could act under their own initiative, had the flexibility to tailor services to customers, and to deal with emergency repairs.

Finding: Front line service providers need discretion to be effective. The case studies revealed how service users needs vary widely over the city. The diversity of operational situations means service 
providers cannot always respond according to formal procedures. The research confirmed that front line workers demonstrated discretion in deciding who gets what and where, prioritising resources and repair work. This was done according to personal, private interests, rather than technical criteria based on efficiency.

\section{- Service providers and users are self-interested}

Service users and providers are essentially deemed self-interested and utility maximising. Strategies of accountability for urban services are often based on the 'primacy of the personal' (Chambers, 1993) and methodological individualism - the well being of society as dependent on individuals and small groups pursuing their own interests.

Finding: The research showed that service providers and users are not necessarily self-interested. Accountability presupposes self-interest and individualism. However, the case studies highlighted instances where providers act altruistically by taking on more work to improve service delivery. This evidence stands in opposition to a critique that blames indifferent and lazy front line providers as obstacles for delivering services to the poor. Service users overcome free rider incentives and take action to improve neighbourhood level services, and further common interest.

Finding: Accountability requires a perception of shared responsibility. Service users are responsible for the O\&M of urban services within their property boundary. However, service providers complain residents are slow to meet their responsibilities. For example, in Seoul residents are required to clean their water tanks once a year and replace their plumbing systems regularly to protect water quality and facilitate the detection of leakage - yet few do so. In Mdantsane officials recognised that residents were still adjusting to their new responsibilities for household level services, which under homeland rule were the responsibility of the local authority.

\section{Finding: Service users and providers have different interests in service delivery, but may share}

wider concerns. Castells $(1977,1983)$ argued that those who administer services, those who provide them, and those who consume them share a common interest in service delivery because they all derive some benefit from the service. However, the research showed that it is more likely that, when faced 
with a problem, there will be fragmentation of interests (Dunleavy, 1980; Saunders 1986). Furthermore, the research found that service users and providers may share wider concerns based on social symmetry in service delivery based on ethnic, religious, family ties to the neighbourhood (Yin, 1982). Accountability was improved where service providers are visible, better known, and more rooted in neighbourhoods where they work and are likely to understand from their own experience what is going on in the neighbourhood.

\section{- User voice is needed for effective service delivery}

The benefits of increased 'voice' in service delivery are to match services outputs to demands, and to discipline service providers. Strengthening service users voice and participation can further increase user satisfaction with service delivery.

Finding: The respondents from deprived areas thought that they did have a voice in service delivery. The research revealed that perceptions of having a voice in service delivery were often associated with respondents living in deprived areas. However it was clear that service providers did not feel equally accountable to all service users and while the poor felt they have a voice in service delivery it is clearly not a very powerful or effective one since service levels in their neighbourhoods remain technically inadequate. VIP people tended to go straight to the Managing Director or the chief engineer with complaints, and had the ability to demand special treatment from service providers, such as not paying the full costs of services.

Finding: User satisfaction may still be low even if services meet technical targets for service

delivery. Securing customer satisfaction has been frustrating for service providers in Seoul, when, despite all their efforts, services are failing to meet the expectations of more informed, motivated, effective and empowered citizens. In Dhaka one service provider stated that even 'if everyone is $100 \%$ satisfied, they will still expect more'. The Project Pathfinder has the best standard of work in Bristol, yet the majority of residents interviewed said there had been no improvements in services or the appearance of the area in the last three years. Similarly, in Buffalo City people expect a higher standard of service than those set out in the RDP, they aren't satisfied with gravel roads, pit latrines and standpipes, even when these are an improvement to previous standards of service. 


\section{IMPLICATIONS OF THE RESEARCH FINDINGS}

This section presents the implications of the research findings for the existing theory and future practice of accountability for the delivery of urban services.

The most striking research finding was that the service user-provider relationship is not always the central dynamic in service delivery. For instance accountability is often carried out through a variety of strategies, which in combination are effective. However multiple strategies of accountability make it difficult to evaluate the contribution of each approach.

Service providers must work closely with politicians, since the research showed that local councillors are often keenly aware of users problems. The scrutiny function of councillors in service delivery requires new ways of working and competencies together with new ways to engage with communities and reflect local priorities. The case studies highlighted the need for balance between decentralisation to respond to needs at local level and central government initiative, coordination and resources.

The evidence that mechanisms to raise consumers voice will discipline service providers is partial. Accountability to users tends to be stronger where users have higher status. More especially, paying user charges is not very effective as leverage to demand better performance and accountability. In the context of developing countries resource constraints in service delivery may make this strategy particularly counterproductive.

Accountability creates greater expectations in service delivery; service providers should be prepared for a dip in satisfaction levels following a reform. High rates of dissatisfaction with urban services suggest potential governance problems. Some respondents had no idea that positive changes had taken place in service delivery; lack of information often means low satisfaction with outputs.

Certain service providers interviewed revealed prejudices against 'the kind of people' that live in lowincome neighbourhoods, they were characterised as troublesome, difficult to please, or threatening, with little self-respect, pride, or dignity. However, accountability worked well where front line 
providers are visible, known in the neighbourhood, and there was some social symmetry in power/class relations. The case studies revealed that service providers can also be a source of neighbourhood pride, broker for power on behalf of residents, and advocate for their rights. Nevertheless, the current focus on the accountability of individual front line provider is at the expense of more general patterns of inequality or discrimination, for which no one actor is responsible.

The research showed that services users are often the most powerful advocates on accountability issues because they can speak with direct experience of service delivery and its consequences. However, people living in deprived areas had different perceptions of rights and worth, which affect the belief that it is possible to challenge service provision, or else mean that people do not perceive an injustice in service delivery. While personal status might not affect the level of participation in service delivery, it does affect the kind of participation selected. In a well-defined geographic area, where the community have been organised and have access to resources, people may be more willing to take action to defend their interests. Accountability for urban services must provide tangible benefits and reduce costs in order to motivate people to monitor service delivery. Sustaining accountability depends on finding ways of keeping users engaged and aware of how their participation makes a difference in decisionmaking and service delivery.

Information collection and dissemination is often ineffective as a proxy for communication with service users/surrogate for political responsiveness. Communities that are presently poor in physical infrastructure are in danger of becoming so in information, thus compounding inequalities and inequities.

Trust is important in service delivery, even where there is no choice in service provider. Local governments recognised urban service delivery as a mechanism to gain citizens' trust. The role of face-to-face communication promotes the establishment of trust and cooperation. Service providers must establish credibility in communities in order to build trust.

Service users do not necessarily want a formal permanent voice in service delivery, but need to be able to re-establish accountability when necessary. Improved service outputs may be better served by 
tailoring mechanisms to a heterogeneous user group. Service providers should consider the 'voice' they use to address service users. This voice must accommodate the different kinds of service users whilst remaining internally coherent and consistent.

Partnerships between local government, NGOs and communities to co-produce urban services were successful where they coordinated activities, ensured regular communication, shared the same goals, set clear objectives, roles and responsibilities, and maintained enthusiasm. Care should be taken to ensure the accountability of these partnerships to the community.

The case studies showed that it is often in the 'commercial' interests of service providers to include accountability arrangements in their business practice. In the long run the costs of accountability (technical, human, financial) can be offset against the benefits of having usable infrastructure over an extended life cycle. Voluntary approaches to accountability can be a public relations exercise, and tend to have unreliable outcomes that are focused on the financial bottom line and are short termist.

\section{CONCLUSIONS}

The research investigated different mechanisms of accountability for urban services, including professional accountability in the design and delivery of services; increasing political participation in representative democracy; increasing user accountability; improving managerial accountability of service providers. The literature on accountability for urban services suggests a number of general conditions for the functioning of accountability. In light of practical experience and empirical data from Bristol (UK), Mdantsane (South Africa), Dhaka (Bangladesh) and Seoul (South Korea), these assumptions were tested to see if accountability is demonstrated in the case studies in the way predicted by the literature. The empirical data demonstrates that factors like multiple strategies and information/resource symmetries are critical to accountability and that there is partial evidence to support the need for sanctions, trust, incentives, self-interest, and user voice for effective service delivery. The research also indicates the need for greater emphasis on the operation and maintenance of urban services and direct accountability to service users. However the assumption that service users should be treated as homogenous is disputed. The implications of the research findings for the existing 
theory and future practice of accountability have been identified. As such, this research has provided better insight into the nature and provision of accountability for urban services. 
References

1. Ahmad, JK. Savage, D., Srivastava, V. (2004) ‘Scaling up Drinking Water Services’, Development Outreach Edition: Client Power Making Services Work for the Poor. http://www1.worldbank.org/devoutreach/article.asp?id=238

2. Casley, J (2003) 'Understanding Service Delivery Reform and Organisational Performance in an Indian State'. 'Making Services Work for Poor People: World Development Report: 2003/4 Workshop.

3. Castells, M. (1977), The Urban Question: A Marxist Approach. London: Edward Arnold.

4. Castells, M. (1983) The City and the Grassroots: a Cross-Cultural Theory of Urban Social Movements. London: Edward Arnold.

5. Chambers in Bernstein, H., Crow, B., Johnson, H. (eds.) (1992) Rural Livelihoods Crisis and Response. Buckingham: Open University Press.

6. Cronin J., Taylor, SA. (1994) 'SERVPERF Versus SERVQUAL: Reconciling PerformanceBased and Perceptions-Minus-Expectations Measurement of Service Quality', Journal of Marketing, Vol. 58, January, pp125-131.

7. Davis, J., Brikke, FB. (1995) Making Your Water Supply Work: Operation and Maintenance of Small Water Supply Systems. Geneva: IRC.

8. Deichmann, U., Lall, SV. (2003) Are You Satisfied? Citizen Feedback and Delivery of Urban Services. Urban Development Policy Research Working Paper, www.econ.worldbank.org/resource

9. Dunleavy, P. (1980) Urban Political Analysis, the politics of collective consumption. London: Macmillan.

10. Ferguson, J. (1994) The Anti-Politics Machine. Cambridge, MA: Cambridge University Press.

11. Goetz, A M and J Gaventa (2001), Bringing Citizen Voice and Client Focus into Service Delivery, Working Paper 138, Institute of Development Studies, Brighton, July.

12. Grindle, M. (2003) First in the Queue? Mainstreaming the Poor in Service Delivery, 'Making Services Work for Poor People. Background paper for the World Development Report2003/4 Workshop.

13. Hardin, G. (1968) ‘The Tragedy of the Commons’, Science, Vol. 162, pp.1243-8. 
14. Hardoy, J., Mitlin, D., Satterthwaite, D. (1992) Environmental Problems in the Third World Cities. London: Earthscan

15. Hart, C., Jones, K., and Bains, M (1997), 'Do the people want power? The social responsibilities of empowering communities’ in Hogget, $\mathrm{P}$ (editor), Contested Communities: Experience, Struggle, Policies, The Policy Press, Bristol, page 197.

16. Jabbra, J G and O P Dwivedi (1989), Public Service Accountability: A Comparative Perspective, Kumarian Press.

17. McGranahan, G., Jacobi, P., Songsore, J., Surjadi, C., Kjellen, M. (2001) The Citizens at Risk: From Urban Sanitation to Sustainable Cities. London: Earthscan.

18. Molyneux, M. (1985) 'Mobilisation without emancipation? Women’s interests, state and revolution in Nicaragua', Feminist Studies, Vol. 11 (No. 2).

19. Moser, C. (1989) 'Gender Planning in the Third World: meeting practical and strategic gender needs', World Development, Vol. 17 (No. 11).

20. Narayan, D., Chambers, R., Shah, MK., Petesch, P. (2000) Voices of the Poor: Crying out for Change. Oxford: Oxford University Press.

21. O’Donnel, G.O., (1999), 'Horizontal Accountability in New Democracies', in Schedler, A., Diamond, G.O., Plattiner, M.F (editors) (1999), The Self-restraining State; Power and Accountability in New Democracies, Lynne Reinner, London, page 17.

22. Osbourne, D. and Gaebler, T. (1993) Reinventing Government: How the Entrepreneurial Spirit is Transforming the Public Sector. New York: Plume.

23. Parkin, S. (2000) 'Sustainable Development: the Concept and the Practical Challenge', Proceedings of the Institution of Civil Engineers, Civil Engineering, Vol. 138, pp. 3-8.

24. Paul, S. (2002) Hold the State to Account; Citizen Monitoring in Action. Bangalore: Public Affairs Centre.

25. Rakodi, C. (2003) What Are The Most Effective Strategies for Understanding and Channelling the Preferences of Service Users to Make Public Services More Responsive. 'Making Services Work for Poor People: World Development Report: 2003/4 Workshop.

26. Republic of South Africa. (1998) Municipal Structures Act. Pretoria: Government Printer.

27. Saunders, P. (1986) Social Theory and the Urban Question. $2^{\text {nd }}$ Edition, London: Hutchinson Education Ltd. 
28. Schedler, A., (1999), 'Conceptualising Accountability’, in Schedler, A., Diamond, G.O., and Plattiner, M.F (editors), see reference 10, pages 2-3.

29. Scott, JC. (1985) Weapons of the Weak: Everyday Forms of Peasant Resistance. New Heaven: Yale University Press.

30. Skelcher, C (1993), “Involvement and empowerment in local public services”, Public Money and Management, July-September, vol. 13, pp13-20

31. Varley, A. (1999) 'A New Model of Urban Land Regularisation in Mexico? The Role of Opposition Government', The European Journal of Development Research, Vol. 11 (No2), pp. 235-61.

32. World Bank. (2004) World Development Report: Making Services Work for Poor People. Washington DC: World Bank.

33. Yin, R. (1982) Conserving America’s Neighbourhoods. New York: Plenum Press.

34. Zeithaml, V. (1988) ‘A Consumer’s Perceptions of Price, Quality, and Value’, Journal Of Marketing, Vol. 52 (No. 3).

35. Grant, KG. (2001) The Crucial role of ethics and continuing development for civil engineers, Journal of Professional Issues in Engineering Education and Practice, April 2001 Vol. 127 (Issue 2) pp 54-56

36. Siller, TJ. (2001) Sustainability and Critical Thinking in Civil Engineering Curriculum, Journal of Professional Issues in Engineering Education and Practice, Vol. 127(issue 3) pp 93-140.

37. Cywinski, Z. Current philosophy of sustainability in civil engineering, Journal of Professional Issues in Engineering Education and Practice, Volume 127 (issue 1) pp12-16.

38. Hunsaker, KL. (2001) The Many obligations of a civil engineer, Journal of Professional Issues in Engineering Education and Practice, Volume 127 Issue 1 pp 9-11.

39. Luce, L. Henry, WP. (2002) Public Awareness of Civil Engineering and the Infrastructure, Journal of Professional Issues in Engineering Education and Practice, Vol. 128 (number 4) pp 165-166.

40. Miller, JB. (2002) The Civil Engineering in Society - Public Policy, Public Office, and Community Service, Journal of Professional Issues in Engineering Education and Practice, Vol. 128 (number 4) pp 161-163 
41. Henry, WP. (2002) Professional issues in civil engineering in the $21^{\text {st }}$ Century, Journal of Professional Issues in Engineering Education and Practice, Vol. 128 (number 4) pp 160-161

42. Cochran, J. (2002) Erasing Ethical Borders, Journal of Professional Issues in Engineering Education and Practice, Vol 128 (no. 3) pp112-115.

43. Rassafi, AA. Bagheri, A. (2002) Discussion of 'current philosophy of sustainability in civil engineering by Zbigniew Cywnski, Journal of Professional Issues in Engineering Education and Practice, Vol. 128 (number 2) pp 94

44. Padmanabhan, G., Katti, D. (2002) Using Community based projects in civil engineering Capstone Courses, Journal of Professional Issues in Engineering Education and Practice, Vol. 128 (Number 1), pp 19-25

45. Rubin, RA., Quitas, B., Roth, D. (2004) Changing Role of the Civil Engineer in Society, Journal of Professional Issues in Engineering Education and Practice, Vol. 130 Number 1, pp 5-8.

46. Steinmann, A. (2003) Implementing Sustainable Development through Problem based learning: Pedagogy and Practice, Journal of Professional Issues in Engineering Education and Practice, Vol 129, NO. 4, pp216-225.

47. Lang, ER. (2003) Applying ethics to engineering, Journal of Professional Issues in Engineering Education and Practice, Vol. 129 (number 3), pp 134-136.

48. Zitomer, DH., Gabor, M., Johnson, P. (2003) Bridge Construction in Guatemala: Linking Social Issues and Engineering, Journal of Professional Issues in Engineering Education and Practice, Vol. 129 (number 3), pp 143-151.

49. Devas, N., Grant, U. (2003) Local government decision making - citizen participation and local accountability: some evidence from Kenya and Uganda, Public Administration and Development, Vol. 23 (Issue 4): pp 307-316

50. Cavill, S., Sohail, M. (2003) “Accountability in the Provision of Urban Services”, Proceedings of the Institution of Civil Engineers; Municipal Engineer, Volume 156, Issue 4.

51. Cavill, S., Sohail, M. (2004) “Strengthening Accountability for Urban Services”, Environment and Urbanisation, Volume 16.

52. World Bank. (2004) World Development Report: Making Services Work for Poor People. Washington DC: World Bank.

53. Chambers, R. (1993) Challenging the Professionals. London: Intermediate Technology Publications.

54. Ackerman, J. (2003) State-Society synergy for accountability: lessons for the World Bank> Washington DC, World Bank. 
Table 1: Research summary

\begin{tabular}{|c|c|c|c|c|}
\hline $\begin{array}{l}\text { Case study } \\
\text { location }\end{array}$ & $\begin{array}{l}\text { Accountability } \\
\text { Problem }\end{array}$ & $\begin{array}{l}\text { Key feature of the } \\
\text { initiative researched }\end{array}$ & $\begin{array}{l}\text { Accountability } \\
\text { arrangement }\end{array}$ & Finding \\
\hline Bristol & $\begin{array}{l}\text { Social Exclusion Unit } \\
\text { demonstrates services perform } \\
\text { well below national average in } \\
\text { the most disadvantaged } \\
\text { neighbourhoods both because of } \\
\text { unfair treatment and } \\
\text { inefficiency. }\end{array}$ & $\begin{array}{l}\text { Improved the design } \\
\text { and delivery of } \\
\text { services. }\end{array}$ & $\begin{array}{l}\text { Project } \\
\text { Pathfinder }\end{array}$ & $\begin{array}{l}\text { 1. } \begin{array}{l}\text { Rapid improvement of service } \\
\text { delivery through dedicated team, } \\
\text { integrated service, and inter- } \\
\text { changeability of team. }\end{array} \\
\text { 2. Importance of both decentralisation } \\
\text { for accountable service delivery and } \\
\text { central government initiative and } \\
\text { resources. } \\
\text { There is a lack of ability to enforce a } \\
\text { response from the private sector } \\
\text { partner on part of community. } \\
\text { Accountability improved by } \\
\text { community development initiatives. } \\
\text { Pathfinder team has substantial } \\
\text { discretion but new pressures to } \\
\text { perform come from the community. }\end{array}$ \\
\hline Mdantsane & $\begin{array}{l}\text { Issues of ineffective service } \\
\text { delivery, inefficiency and lack of } \\
\text { equity in service delivery. }\end{array}$ & $\begin{array}{l}\text { Increased political } \\
\text { participation. }\end{array}$ & Ward committees & $\begin{array}{l}\text { 1. } \begin{array}{l}\text { Ward committee mechanism is } \\
\text { grounded in pre-existing social } \\
\text { practice (although post apartheid } \\
\text { experiences of area based } \\
\text { committees has been relatively } \\
\text { unsuccessful). }\end{array} \\
\text { 2. } \quad \begin{array}{l}\text { Ward Committee is a loose } \\
\text { arrangement with little scope for } \\
\text { residents to monitor progress of } \\
\text { complaint or monitor day-to-day }\end{array} \\
\text { performance. } \\
\text { 3. Ward committees deal with } \\
\text { residents' complaints, and have a } \\
\text { role in supervising and coordinating } \\
\text { delivery of services in their zones. } \\
\text { Perceived legitimacy of community } \\
\text { representatives on ward committees. } \\
\text { Community has high expectations } \\
\text { and are frustrated by the slow pace of } \\
\text { change. }\end{array}$ \\
\hline Dhaka & $\begin{array}{l}\text { Ineffective service delivery, } \\
\text { clientelism and corruption. }\end{array}$ & $\begin{array}{l}\text { Increased the } \\
\text { influence of service } \\
\text { users. }\end{array}$ & $\begin{array}{l}\text { Citizen Score } \\
\text { card } \\
\text { NGO delivery }\end{array}$ & $\begin{array}{l}\text { 1. Success of scorecard crucially } \\
\text { depends on the degree of follow-up } \\
\text { activity and an enabling social and } \\
\text { political context. } \\
\text { 2. Society driven accountability } \\
\text { requires reformers on the 'inside' } \\
\text { government and service providers to } \\
\text { work. } \\
\text { 3. There is potential for active } \\
\text { participation of poorest in } \\
\text { accountable service delivery. } \\
\text { User accountability can be improved } \\
\text { by the institutionalisation of } \\
\text { mechanisms in law/policy. } \\
\text { There is the potential for grassroots } \\
\text { pressure groups to promote integrity } \\
\text { in services. }\end{array}$ \\
\hline Seoul & $\begin{array}{l}\text { Widespread red tape and } \\
\text { corruption in service delivery. }\end{array}$ & $\begin{array}{l}\text { Improved the } \\
\text { responsiveness of } \\
\text { service providers. }\end{array}$ & $\begin{array}{l}\text { Anti-corruption } \\
\text { oriented } \\
\text { managerial } \\
\text { reform }\end{array}$ & $\begin{array}{ll}\text { 1. } & \text { Problem of top down planning } \\
\text { 2. Importance of transparency in } \\
\text { society } \\
\text { 3. }\end{array}$ \\
\hline
\end{tabular}


Table 2: Summary of Findings from Testing Propositions

\begin{tabular}{|c|c|c|c|c|}
\hline Proposition & The overall effect practice has on proposition & Finding & & \\
\hline & Comment & Support & $\begin{array}{l}\text { Partially } \\
\text { support }\end{array}$ & Dispute \\
\hline Multiple strategies & $\begin{array}{l}\text { There is a need to review how accountability is defined. } \\
\text { Respondents from deprived areas use different strategies to } \\
\text { cope with failing services. Accountability is not something that } \\
\text { is achieved once and for all. Accountability only exists insofar } \\
\text { as people make it exist by using it. }\end{array}$ & $\mathrm{X}$ & & \\
\hline $\begin{array}{l}\text { Information and } \\
\text { other resource } \\
\text { symmetries }\end{array}$ & $\begin{array}{l}\text { Information asymmetries have been reduced in service } \\
\text { delivery. Information asymmetries can be reduced through } \\
\text { dialogue. Accountability has a number of costs. }\end{array}$ & $\mathrm{X}$ & & \\
\hline $\begin{array}{l}\text { O\&M doesn't work } \\
\text { in practice }\end{array}$ & $\begin{array}{l}\text { O\&M of urban services is often not a priority for } \\
\text { municipalities. Effective O\&M was improved by partnerships } \\
\text { and innovation in service delivery. Accountability also applies } \\
\text { to service provider agencies. The case studies showed that the } \\
\text { most important outputs of service delivery are not always } \\
\text { measurable. }\end{array}$ & & $\mathrm{X}$ & \\
\hline $\begin{array}{ll}\text { Sanctions } & \text { are } \\
\text { needed } & \text { for } \\
\text { accountability } & \end{array}$ & $\begin{array}{l}\text { In practice, service users have few sanctions to use as leverage } \\
\text { to demand better services. The role of payment for services as } \\
\text { a sanction in service delivery. Embedding service providers in } \\
\text { communities can be a dis-incentive to front line service } \\
\text { providers. Forms of accountability can be traded off against } \\
\text { each other. International pressures can be effective in making } \\
\text { urban service delivery accountable to citizens. }\end{array}$ & & $\mathrm{X}$ & \\
\hline $\begin{array}{l}\text { Providers are } \\
\text { untrustworthy }\end{array}$ & $\begin{array}{l}\text { Trust does matter in service delivery. Levels of trust vary with } \\
\text { the type of service provider. }\end{array}$ & & $\mathrm{X}$ & \\
\hline $\begin{array}{l}\text { Homogeneous } \\
\text { service users }\end{array}$ & $\begin{array}{l}\text { Some groups in society are better placed for acting on } \\
\text { accountability arrangements. Service providers have attempted } \\
\text { to entrench their interests in service delivery. Focusing on } \\
\text { individual accountability of front line service providers is a } \\
\text { symptomatic approach to a structural problem. }\end{array}$ & & & $\mathrm{X}$ \\
\hline $\begin{array}{l}\text { Service providers } \\
\text { should be } \\
\text { answerable to the } \\
\text { community }\end{array}$ & $\begin{array}{l}\text { Accountability is shaped by broader socio-political context. } \\
\text { Political accountability continues to have an important role in } \\
\text { service delivery. Accountability of service providers depends } \\
\text { on a degree of direct answerability to the community. Thought } \\
\text { should be given to how to scale up accountability from the } \\
\text { project context. The extent to which accountability have made } \\
\text { society more governable is debateable. }\end{array}$ & & $\mathrm{X}$ & \\
\hline $\begin{array}{lr}\text { Service } & \text { providers } \\
\text { and users need } \\
\text { incentives } & \text { for } \\
\text { action }\end{array}$ & $\begin{array}{l}\text { Users don't necessarily require individual incentives to } \\
\text { improve service delivery. Recognition should be give to the } \\
\text { range of motivation affecting service providers. Front line } \\
\text { service providers need discretion to be effective. }\end{array}$ & & $\mathrm{X}$ & \\
\hline $\begin{array}{l}\text { Service providers } \\
\text { and users are self- } \\
\text { interested }\end{array}$ & $\begin{array}{l}\text { The research showed that service providers and users are not } \\
\text { necessarily self-interested. Service users and providers have } \\
\text { different interests in service delivery, but may share wider } \\
\text { concerns. Accountability requires a perception of shared } \\
\text { responsibility. }\end{array}$ & & $\mathrm{X}$ & \\
\hline $\begin{array}{lr}\text { User } & \text { voice } \\
\text { needed } & \text { is } \\
\text { effective } & \text { for } \\
\text { delivery } & \end{array}$ & $\begin{array}{l}\text { The respondents from deprived areas thought that they did } \\
\text { have a voice in service delivery. Respondents from deprived } \\
\text { areas used collective rather than individual mechanisms to } \\
\text { enforce accountability. Variable outcomes of complaint } \\
\text { handling mechanisms. Accountability can reduce user } \\
\text { satisfaction even if services meet technical targets for service } \\
\text { delivery. }\end{array}$ & & $\mathrm{X}$ & \\
\hline
\end{tabular}

